\section{Pure Representational Neglect After Right Thalamic Lesion}

Stéphanie Ortigue, MS, ${ }^{1}$ Isabelle Viaud-Delmon, PhD, ${ }^{1}$ Jean-Marie Annoni, MD, ${ }^{1}$ Theodor Landis, MD, ${ }^{1}$ Christoph Michel, PhD, ${ }^{1}$ Olaf Blanke, MD,${ }^{1}$ Patrik Vuilleumier, MD, ${ }^{2}$ and Eugène Mayer, $\mathrm{PhD}^{1}$

\begin{abstract}
After a right thalamic stroke, an 86-year-old man presented an acute pure left representational neglect in the absence of any perceptual neglect. On spatial mental imagery tasks, the patient systematically omitted items located on his left side, but only when a vantage point was given. This suggests that (1) pure representational neglect is not just a residual finding after recovery from global (perceptual and representational) neglect; (2) space representation can be coded by two independent processes: in viewer-centered or world-based (allocentric) coordinates; and (3) the right thalamus serves as a relay in the processing of spatial visual imagery.
\end{abstract}

Ann Neurol 2001;50:401-404

Unilateral neglect is generally defined as an impaired ability to detect stimuli in the contralesional hemispace. Neglect can occur when a patient actually sees environmental space (perceptual neglect), but also when he imagines the space without being there (representational neglect). ${ }^{1}$

Left and right hemispace can be defined with respect to viewer-centered and environment-centered or object-centered (allocentric) frames of reference. ${ }^{2}$ Viewer-centered coordinates involve the ability to locate objects with reference to the subject's own body, ${ }^{3}$ whereas allocentric coordinates determine where something lies in the world with reference to the environment itself. ${ }^{4}$ The allocentric frame of reference implies that relationships among multiple landmarks are coded and stored independently of the position of the subject's body. Perceptual neglect is typically based on viewer-centered frames of reference, ${ }^{5}$ although relative

From the ${ }^{1}$ Functional Brain Mapping Laboratory and Neuropsychological Unit, Department of Neurology, University Hospital of Geneva, Switzerland; and ${ }^{2}$ Institute of Cognitive Neuroscience, University College London, London, United Kingdom.

Received Feb 26, 2001, and in revised form Jun 4. Accepted for publication Jun 4, 2001.

Address correspondence to Dr Ortigue, Functional Brain Mapping Laboratory, Department of Neurology, Geneva University Hospital, 24 rue Micheli-du-Crest, CH-1211 Geneva 14, Switzerland. E-mail: stephanie. ortigue@hcuge.ch environment-centered coordinates may also be involved. ${ }^{6,7}$ Representational neglect may similarly involve both viewer-centered and allocentric coordinates; mental imagery could preferentially operate on stored representations independent of the viewer position. However, to our knowledge, viewer-centered and allocentric coordinate frames have not yet been dissociated in representational neglect. Pure representational neglect, confined to internally generated representations of visual images ${ }^{8-11}$ is much less frequent than perceptual neglect with ${ }^{1,12-15}$ or without ${ }^{2,8,12}$ representational neglect. Because in 1 patient, representational neglect appeared as a pure deficit only after an initially concomitant perceptual neglect recovered, representational neglect has been considered as a dynamic phenomenon of recovery from a global (perceptual and representational) neglect syndrome. ${ }^{12}$ Finally, there is also evidence that representational and perceptual neglect might be dissociated with respect to lesion location. ${ }^{8,9}$ However, pure representational neglect has only been described following cortical lesions. Here, we describe a patient who presented a pure left representational neglect following a right thalamic infarction.

\section{Patient and Methods}

This 86-year-old right-handed man suffered from an acute onset of dysarthria and a moderate left hemiparesis without hemisensory loss, which recovered completely within 2 weeks. Magnetic resonance imagine (MRI) 1 week after admission showed a recent right thalamic ischaemic lesion in the dorsomedial nucleus of the thalamus extending into the pulvinar (Fig 1).

On admission, the patient was oriented and aware of his motor deficit. A detailed neuropsychological examination on the fifth day was normal except for impairment in figural fluency ${ }^{16}$ and a strong left representational neglect. There was no perceptual neglect and no tactile, auditory, or visual extinction. Mental imagery outside the spatial domain was unaffected: drawing and verbal description from memory of objects and animals, oral spelling tasks, and a body imagery test ${ }^{10}$ were flawless. All tasks were administrated on several occasions from the fifth day after admission.

A general neuropsychological examination revealed that the patient had no aphasic deficit and no clinical deficit in long-term memory (percentile 50 on the Buschke Selective Reminding Test; percentile 10 on Rey's signs). In short-term memory, his scores were in the normal range (percentile 75 on the digit span; percentile 50 on the Corsi block-span). His performance was in the lower range (percentile 25) on the Topographical Recognition Memory subtest of the Camden Memory Tests, and in the normal range in the Benton Visual Discrimination Test (41 of 54).

\section{Assessment of Perceptual Neglect}

In order to examine neglect in extrapersonal space, ${ }^{17}$ four different tasks were given both in near (NS) and far (FS) space $^{18}$ : a line bisection task and three cancellation tasks with letters, digits, or lines. In addition, other tasks were given in 


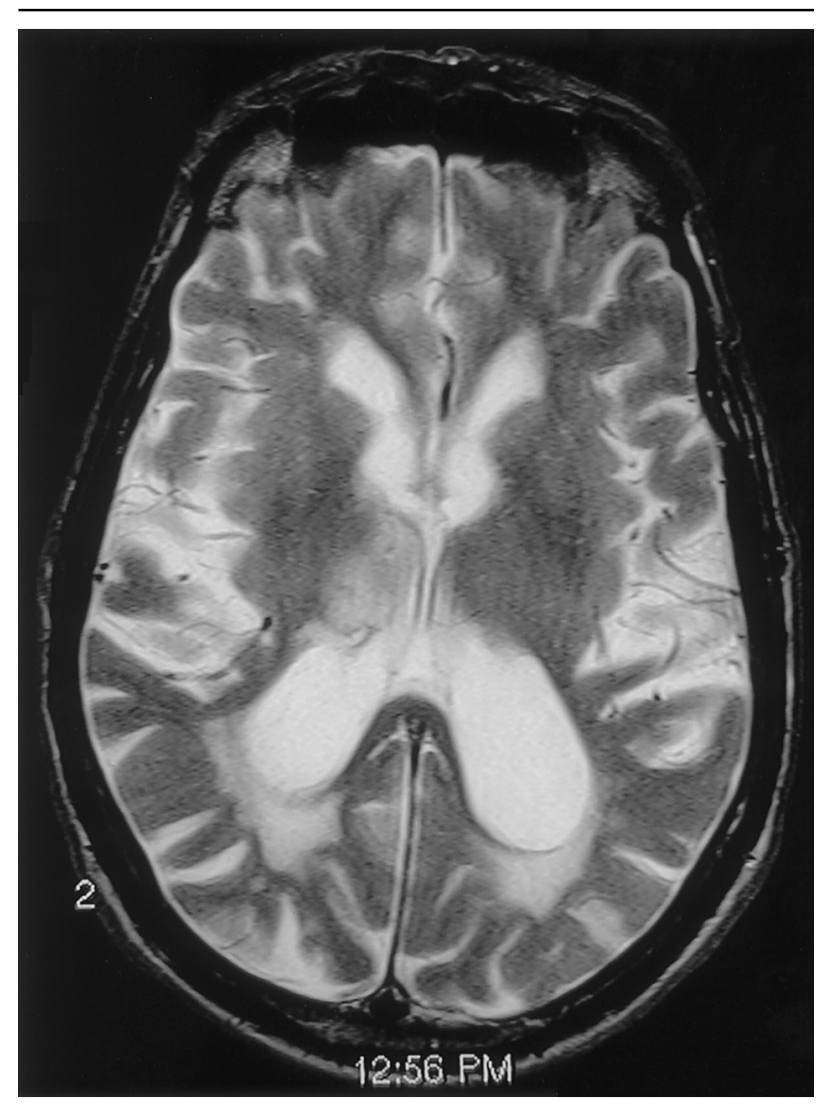

Fig 1. Brain magnetic resonance imaging performed on the ninth day after hospitalization. Axial T2-weighted MR image showing a right thalamic lesion including the dorsomedial nucleus and the pulvinar.

the NS condition including a landscape copying task, a star cancellation task, clock copying task, word ( $\mathrm{n}=10$ per condition) and sentence ( $\mathrm{n}=3$ per condition) reading in horizontal, vertical, and mirror (only for words) positions.

\section{Assessment of Representational Neglect}

In order to dissociate the representational frames of reference, two different conditions, involving viewer-centered and allocentric spatial coordinates were administrated in a counterbalanced order. Performance remained stable during the whole period of investigation.

VIEWER-CENTERED CONDITION. The patient was asked to mentally visualize a familiar square: the Place Neuve in Geneva (local version of Bisiach's test ${ }^{1}$ ). Using four different given vantage points (Fig $2 \mathrm{~A}-\mathrm{C}$ ), he had to describe and to draw the Place Neuve from memory, imagining he could only move the head and the eyes from right to left and left to right but not walk.

Vantage points included conditions emphasizing viewercentered imagery: (1) facing the theatre with his back against the park gate; (2) back against the theatre's door facing the park gate (opposite position); (3) his right shoulder against the park gate, so that the entire square is on the left side of

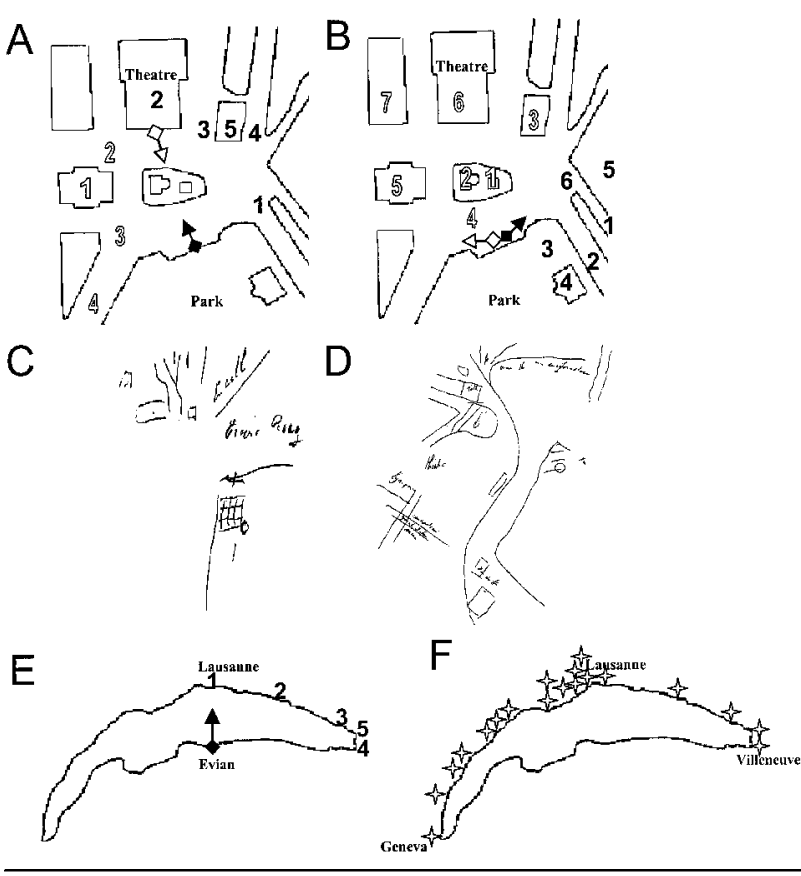

Fig 2. (A and B) Maps of a familiar square verbally described from mental imagery (viewer-centered condition). Vantage points are indicated by squares with an arrow pointing in the viewing direction. Black digits refer to the details reported from vantage points indicated with black squares and black arrows, while white digits refer to the details reported from opposite vantage points indicated with white squares and white arrows. Digits indicate the order in which the details were reported. (C) Patient's drawing corresponding to the vantage point indicated with black square and black arrow in B. (D) Patient's drawing of the square without an imposed vantage point, demonstrating his preserved recall in the allocentric condition. (E) Cities along the lake of Geneva reported when a vantage point (black square and black arrow) was given (viewer-centered condition). (F) Cities reported without an imposed vantage point (allocentric condition).

his body; and (4) his left shoulder against the park gate (inverse position).

In a second task, he was asked to list all the towns he could mention on the Swiss coast of the lake of Geneva, as seen from a hypothetical vantage point on the opposite French coast (see Fig 2E). He had to imagine himself in Evian (a French city along the lake), looking toward Lausanne (a Swiss city facing Evian).

The patient's responses were recorded in the two tasks and compared with his performance in the allocentric condition, which could thus serve as his own control.

ALLOCENTRIC CONDITION (WORLD-CENTERED). The patient was asked to draw and to describe a maplike representation of the Place Neuve without requiring any specific vantage point (see Fig 2D). He was told: "Describe the Place Neuve as you would explain it to a tourist." Again, in a second task, his topographical knowledge of the lake of Geneva was assessed by asking him to give the maximum of names of 
cities along the lake between Geneva and Villeneuve, two cities located at both extremities of the lake (see Fig 2F).

\section{Results}

Assessment of Perceptual Neglect

Performance was flawless in all NS (mean deviation $=$ $+3 \mathrm{~mm} \mathrm{4}$ ) and FS (mean deviation $=+3 \mathrm{~mm} \mathrm{4}$ ) conditions. There was no significant deviation in line bisection. There was no omission in the cancellation tasks. Exploration of the visual stimuli during the cancellation tasks was indifferently started from the left or right side of paper sheets, revealing no consistent spatial bias overall. Copying and reading tasks were not impaired by neglect-related errors.

\section{Assessment of Representational Neglect}

VIEWER-CENTERED CONDITION. A strong representational neglect was observed in the different imagery tasks in the viewer-centered condition. When asked to describe or to draw the Place Neuve, the patient systematically omitted elements on the left of his imaginary self-position (Table, see Fig $2 \mathrm{~A}-\mathrm{C}$ ). In the second task, five cities were named on the right side of the lake of Geneva, versus none on the left (see Fig 2E).

ALlocentric CONDITION. Performance in this condition strikingly contrasted with performance in the previous viewer-centered condition. In the first task, the patient correctly described and drew a maplike representation of the Place Neuve without omission (see Fig 2D). In the second task, he reported 19 cities between Geneva and Villeneuve, demonstrating his preserved topographical knowledge (see Fig 2F).

\section{Discussion}

This patient showed pure left representational neglect. Although mental imagery was preserved for nonspatial information and long-term and short-term spatial memory were normal, he omitted the left half of space when imagining visual scenes. Furthermore, representational neglect was found only when a vantage point

Table. Patient Data: Description of a Familiar Place in the Viewer-Centered Condition ${ }^{\mathrm{a}}$

\begin{tabular}{lccccc}
\hline & \multicolumn{2}{c}{ Verbal Description } & & \multicolumn{2}{c}{ Drawings } \\
\cline { 2 - 3 } \cline { 5 - 6 } $\begin{array}{l}\text { Vantage } \\
\text { Points }\end{array}$ & $\begin{array}{c}\text { Left } \\
\text { Hemispace }\end{array}$ & $\begin{array}{c}\text { Right } \\
\text { Hemispace }\end{array}$ & & $\begin{array}{c}\text { Left } \\
\text { Hemispace }\end{array}$ & $\begin{array}{c}\text { Right } \\
\text { Hemispace }\end{array}$ \\
\hline 1 & $0 / 5$ & $5 / 6$ & & $0 / 5$ & $4 / 6$ \\
2 & $0 / 6$ & $4 / 5$ & & $0 / 6$ & $3 / 5$ \\
3 & $1 / 11$ & & & $0 / 11$ & \\
4 & & $6 / 11$ & & & $7 / 11$ \\
\hline
\end{tabular}

${ }^{a}$ Number of items reported, according to the four imposed vantage points and to their distribution in left and right hemispace, referenced to the number of items reported in the allocentric condition. was imposed. By contrast, when the task instruction emphasized an allocentric instead of viewer-centered reference frame, the patient did not show any neglect.

These data show that representational neglect may present as a first isolated, acute, neuropsychological symptom after a stroke. In the four previous cases of pure left representational neglect, neuropsychological examination was carried out quite late after lesion onset (2 years, ${ }^{8} 16$ months, ${ }^{9} 2^{1 / 2}$ months, ${ }^{10} 45$ days $\left.{ }^{11}\right)$. This delay led some authors to conclude that representational neglect does not exist as an independent entity but may rather reflect a difference in recovery rate between performance in perceptual and mental imagery tasks. ${ }^{12}$ Our patient was investigated in the acute phase and our findings thus provide strong evidence in support of an initial dissociation between perceptual and representational neglect. ${ }^{8-11}$

In addition, these findings also demonstrate dissociation between two frames of reference (viewer-centered versus allocentric) in spatial mental imagery. Indeed, in spite of a clear instruction to imagine looking around him, ${ }^{14}$ our patient was unable to describe from memory both sides of a familiar place when mental representation had to be generated in relation to his own body position in the imagined scene, even though he did it perfectly when he only used knowledge about spatial relationships independent of his own body position. This preservation of topographical knowledge directly indicates that representational neglect was not a result of memory impairment but rather a result of a disorder in mental imagery processes operating in a body-centered system. These findings thus demonstrate that an imaginary viewer-centered vantage point can critically influence representational neglect. However, whether this reflects a deficit in generating mental images from memory or an impairment of attentionalactivational mechanisms necessary to scan and verbally report these mental images ${ }^{14}$ cannot be distinguished.

Finally, unlike previous case descriptions of pure representational neglect that were all exhibited after cortical lesions, MRI in our patient showed a lesion confined to the right dorsomedial thalamus, suggesting a critical implication of thalamic structures in mental imagery when a viewer-centered vantage point is given. The present findings indicate that the spatial representational network is not only cortico-cortical but also cortico-subcortical. ${ }^{19}$ Separate neural systems may convey distinct spatial frames, respectively using viewercentered and allocentric information. ${ }^{20}$ We conjecture that the right thalamus, with its reciprocal connections with cortical areas, may serve as a major relay in the processing of viewer-centered mental imagery. However, it remains to be established whether a thalamic lesion in itself may directly be responsible for representational neglect, or whether some cortical involvement 
caused by remote diaschisis effects are necessary for the occurrence of such cognitive spatial disorders. ${ }^{19}$

This work was supported by the Programme Commun de Recherche en Génie Biomédical from 1999 to 2002, and the Swiss National Research Foundation (31-61680.00 and 3100-057112.99).

\section{References}

1. Bisiach E, Luzzatti C. Unilateral neglect of representational space. Cortex 1978;14:129-133.

2. Grüsser OJ, Landis T. Visual agnosias and other disturbances of visual perception and cognition, Vol. 12. Cronly-Dillon JR, ed. London: Macmillan, 1991.

3. Pizzamiglio L, Guariglia C, Cosentino T. Evidence for separate allocentric and egocentric space processing in neglect patients. Cortex 1998;34:719-730.

4. Snyder LH, Grieve KL, Brotchie P, Andersen RA. Separate body- and world-referenced representations of visual space in parietal cortex. Nature 1998;394:887-891.

5. Driver J, Pouget A. Object-centered visual neglect, or relative egocentric neglect? J Cogn Neurosci 2000;12:542-545.

6. Mennemeier M, Chatterjee A, Heilman KM. A comparison of the influences of body and environment centered reference frames on neglect. Brain 1994;117:1013-1021.

7. Ladavas E. Is the hemispatial deficit produced by right parietal lobe damage associated with retinal or gravitational coordinates? Brain 1987;110:167-180.

8. Coslett HB. Neglect in vision and visual imagery: a double dissociation. Brain 1997;120:1163-1171.

9. Guariglia C, Padovani A, Pantano P, Pizzamiglio L. Unilateral neglect restricted to visual imagery. Nature 1993;364:235-237.

10. Beschin N, Cocchini G, Della Sala S, Logie RH. What the eyes perceive, the brain ignores: a case of pure unilateral representational neglect. Cortex 1997;33:3-26.

11. Peru A, Zapparoli P. A new case of representational neglect. Ital J Neurol Sci 1999;20:243-246.

12. Bartolomeo P, D'Erme P, Gainotti G. The relationship between visuo-spatial and representational neglect. Neurology 1994;44:1710-1714.

13. Cambier J, Graveleau PH. Thalamic syndromes. In: Fredericks JAM, ed. Handbook of Clinical Neurology vol. 1 (45). Amsterdam: Elsevier Science, 1985:87-98.

14. Meador KJ, Loring DW, Bowers D, Heilman KM. Remote memory and neglect syndrome. Neurology 1987;37:522-526.

15. Beschin N, Basso A, Della Sala S. Perceiving left and imagining right: dissociation in neglect. Cortex 2000;36:401-414.

16. Regard M, Strauss E, Knapp P. Children's production on verbal and non-verbal fluency tasks. Percept Motor Skills 1982;55: 839-844.

17. Halligan PW, Marshall JC. Left neglect for near but not far space in man. Nature 1991,11;350:498-500.

18. Vuilleumier P, Valenza N, Mayer E, et al. Near and far visual space in unilateral neglect. Ann Neurol 1998;43:406-410.

19. Demeurisse G, Hublet C, Paternot J, et al. Pathogenesis of subcortical visuo-spatial neglect. A HMPAO SPECT study. Neuropsychologia 1997;35:731-735.

20. Galati G, Lobel E, Vallar G, et al. The neural basis of egocentric and allocentric coding of space in humans: a functional magnetic resonance study. Exp Brain Res 2000;133:156-164.

\section{Elevated Corticotropin Releasing Hormone/ Corticotropin Releasing Hormone-R1 Expression in Postmortem Brain Obtained from Children with Generalized Epilepsy}

Wei Wang, MD, ${ }^{1}$ Kimberly E. Dow, MD, ${ }^{1}$ and Douglas D. Fraser, $\mathrm{MD}, \mathrm{PhD}^{1-3}$

The corticotropin releasing hormone (CRH) system has been suggested to initiate seizure activity in the developing brain. However, human data to support this theory is lacking. In this study, we have demonstrated that the expression of CRH, CRH-binding protein, and CRH-R1 (a CRH membrane receptor) were significantly elevated in cortical tissue obtained from 6 children with generalized epilepsy (mean age $8.2 \pm 1.5$ years) relative to agematched controls (mean age $7.8 \pm 1.4$ years). In contrast, no significant difference in the expression of CRH-R2 was observed. The advent of CRH-R1 receptor antagonists may prove useful as novel anticonvulsants.

Ann Neurol 2001;50:404-409

Corticotropin releasing hormone (CRH) is expressed in both cortical and limbic structures and is implicated in seizure genesis during development. ${ }^{1}$ Stressful events cause a rapid expression of the $\mathrm{CRH}$ gene ${ }^{2}$ and local $\mathrm{CRH}$ release. ${ }^{3} \mathrm{CRH}$ activates membrane receptors (CRH-R1 and/or CRH-R2) ${ }^{4}$ to elicit cellular responses before being inactivated by the $\mathrm{CRH}$-binding protein (CRH-BP). ${ }^{5}$ While low concentrations of CRH cause moderate neuronal excitation, excessive $\mathrm{CRH}$ receptor stimulation causes overt seizure activity. ${ }^{6,7}$ Conversely, increased CRH expression is observed in animal models following seizure activity precipitated by either electrical stimulation ${ }^{8}$ or kainic acid administration. ${ }^{9}$ In-

From the ${ }^{1}$ Department of Paediatrics, Kingston General Hospital, Kingston, Ontario; ${ }^{2}$ Department of Anatomy and Cell Biology, Queen's University, Kingston, Ontario, Canada; and ${ }^{3}$ Clinical Trials Group, Canadian Paediatric Epilepsy Network (CPEN), Canada.

Received Dec 8, 2000, and in revised form Mar 29, 2001. Accepted for publication Jun 5, 2001.

Address correspondence to Dr Fraser, Department of Pediatrics, Division of Critical Care Medicine, Children's Hospital of Eastern Ontario, 401 Smyth Road, Ottawa, Ontario K1H 8L1, Canada. E-mail: drfraser@hotmail.com 
creased CRH immunoreactivity is also observed in an epileptic rat strain exhibiting spontaneous tonic-clonic seizures. ${ }^{10}$ Upregulation of the $\mathrm{CRH}$ system may therefore precipitate seizure activity or represent an adaptive response supporting ongoing epileptogenesis. In young animals, CRH-induced excitation is mediated specifically by CRH-R1. ${ }^{11}$ The advent of appropriate therapeutic agents to maintain the $\mathrm{CRH}$ system at a reduced level of activity (ie, CRH-R1 receptor antagonists $)^{4}$ may therefore prove useful as novel anticonvulsant medication.

While numerous animal studies have implicated the $\mathrm{CRH}$ system in seizure genesis, no human data exist to corroborate these findings. The aim of this study, therefore, was to determine whether alterations in the brain CRH system are associated with epilepsy in children. To this end, we have measured mRNA (RTPCR) and protein (RIA) levels in postmortem brain obtained from children with generalized epilepsy and age-matched controls. More specifically, we examined the relative cortical expression levels of $\mathrm{CRH}, \mathrm{CRH}-$ BP, CRH-R1, and CRH-R2.

\section{Materials and Methods}

Postmortem brain was obtained from the Brain and Tissue Bank for Developmental Disorders, in contract to the NICHD. Tissue samples consisted of hemicoronal sections of frozen cortex, neuronal layers I to VI. Inclusion criteria for the postmortem tissue samples included the availability of frozen cortical tissue, a postmortem interval $\leq 36$ hours, a documented medication list, and a detailed medical examiner's report. Postmortem tissue samples were excluded if agematched controls were not available or if systemic steroids were administered prior to the time of death. All experiments were performed blind with regard to the patient status.

Total RNA was isolated from thawed cortical tissue by the acid guanidinum thiocyanate-phenol-chloroform method and reverse transcribed with AMV reverse transcriptase (Promega). An aliquot of reverse transcription mixture $(2.0 \mu \mathrm{l})$ was amplified by PCR for 30 cycles with the following cycle parameters: $94^{\circ} \mathrm{C}, 1$ minute; $55^{\circ} \mathrm{C}, 1$ minute; $72^{\circ} \mathrm{C}, 2$ minutes. Kinetic studies of each gene were performed to give a linear range of amplification before semiquantitative analysis. Photographs of the gels were scanned and quantitated using computer-assisted linear scanning densitometer (Digitizer-IM 1280; Matrox, Vienna, Austria). The primers chosen to assess mRNA were: CRH (360 bp), 5'-CAACTTTTTCCGCGTGTTGCT-3' and 5'-ATGGCATAAGAGCAGCGCTAT-3'; CRH-BP (634 bp), 5'-GTTCATTACCATCCACTACGA-3' and 5'-CTCCAGCTGACGATACTCAAA-3'; CRH-R1 (476 bp), 5'-ACAAACAATGGCTACCGGGAG-3' and 5'ACACCCCAGCCAATGC AGAC-3'; CRH-R2 (615 bp), 5'-TGTGGAAGGCTGCTACCTG-3' and 5'-GTCTGCTTGATGCTGTGGAA-3'; $\beta$-actin (340 bp), 5' -CAAGAGATGGCCACGGCTGCT-3' and 5'-TCCTTCTGCATCCTGTCGGCA-3'. The data were expressed as mean \pm standard error. Differences between groups were compared by ANOVA (analysis of variance) or by Kruskal-Wallis oneway analysis of variance on ranks.
Tissue lysates were incubated with rabbit anti-hCRH serum (IgG Corp., Nashville, TN) or CRH-BP antibody 5144 (Dr W. Vale, The Salk Institute, La Jolla, CA) in RIA buffer, followed by incubation with $\left[{ }^{125} \mathrm{I}\right] \mathrm{Tyr}{ }^{\mathrm{O}}$-rat/human CRH (Du Pont-New England Nuclear, Boston, MA). Goat anti-rabbit gamma globulin was then added and the samples were precipitated by centrifugation. The pellet radioactivity was measured using a gamma counter.

\section{Results}

A total of 12 postmortem brain samples (6 generalized epilepsy, 6 age-matched controls) were analyzed for the expression of CRH, CRH-BP, CRH-R1 and CRH-R2. The patient demographics are listed in the Table. The age difference between a child with epilepsy and their age-matched control was less than 1 year. The mean age for patients with generalized epilepsy and agematched controls were $8.2 \pm 1.5$ and $7.8 \pm 1.4$, respectively.

Semiquantitative RT-PCR and RIA were used to measure the expression of CRH mRNA and protein, respectively. The expression of CRH mRNA (360 bp) was significantly elevated in all children with epilepsy relative to their age-matched controls $(\mathrm{n}=6 / 6$; $p<0.05$ ). In the children with epilepsy, the mean increase in the expression of CRH mRNA and protein was $31 \%$ and $66 \%$, respectively (Fig 1A-C). Both semiquantitative RT-PCR and RIA also demonstrated elevated CRH-BP expression in children with generalized epilepsy. A significant elevation in CRH-BP mRNA (634 bp) was observed in the majority of children with epilepsy relative to their age-matched controls $(\mathrm{n}=4 / 6 ; p<0.05)$. In the children with epilepsy, the mean increase in expression of CRH-BP mRNA and protein was $51 \%$ and $92 \%$, respectively (see Fig 1D-F).

A significant elevation of CRH-R1 mRNA (476 bp) was also demonstrated, via semiquantitative RT-PCR, in the majority of children with epilepsy relative to their age-matched control $(\mathrm{n}=5 / 6 ; p<0.05)$. Overall, the children with epilepsy expressed $58 \%$ more CRH-R1 mRNA (Fig 2A and B). In contrast, CRH-R2 mRNA (615 bp) was significantly elevated in only 1 child with epilepsy relative to their age-matched control ( $\mathrm{n}=1 / 6 ; p<0.05$ ). When the CRH-R2 mRNA values from all postmortem brain tissue were averaged, the minimal increase in expression was not statistically significant (see Fig 2C and D). The percent difference in CRH-R2 mRNA expression between children with epilepsy and their age-matched controls was only $13 \%$.

\section{Discussion}

Alterations in the CRH system have been implicated in seizure genesis during development. ${ }^{1}$ There have been no human studies, however, to corroborate this theory. 


\begin{tabular}{|c|c|c|c|c|c|c|c|}
\hline & $\begin{array}{l}\text { Age } \\
(\mathrm{yr})\end{array}$ & Sex & Seizure Diagnosis & Medications & Cause of Death & $\begin{array}{l}\text { Postmortem } \\
\text { Interval } \\
\text { (hr) }\end{array}$ & $\begin{array}{l}\text { Tissue } \\
\text { Sample }\end{array}$ \\
\hline $\begin{array}{l}\text { Epilepsy } \\
\text { Control }\end{array}$ & $\begin{array}{l}5 \\
4\end{array}$ & $\begin{array}{l}\mathrm{F} \\
\mathrm{M}\end{array}$ & Tonic-clonic & $\begin{array}{l}\text { None } \times 1 \text { yr } \\
\text { None }\end{array}$ & $\begin{array}{l}\text { Unknown } \\
\text { Hanging }\end{array}$ & $\begin{array}{l}36 \\
19\end{array}$ & $\begin{array}{l}\text { Frontal } \\
\text { Frontal }\end{array}$ \\
\hline $\begin{array}{l}\text { Epilepsy } \\
\text { Control }\end{array}$ & $\begin{array}{l}6 \\
6\end{array}$ & $\begin{array}{l}M \\
M\end{array}$ & Tonic-clonic & $\begin{array}{l}\text { Phenytoin } \\
\text { None }\end{array}$ & $\begin{array}{l}\text { Unknown } \\
\text { Drowning }\end{array}$ & $\begin{array}{l}21 \\
21\end{array}$ & $\begin{array}{l}\text { Parietal } \\
\text { Parietal }\end{array}$ \\
\hline $\begin{array}{l}\text { Epilepsy } \\
\text { Control }\end{array}$ & $\begin{array}{l}6 \\
7\end{array}$ & $\begin{array}{l}\mathrm{F} \\
\mathrm{M}\end{array}$ & Severe myoclonic & $\begin{array}{l}\text { Valproate } \\
\text { None }^{\mathrm{a}}\end{array}$ & $\begin{array}{l}\text { Unknown } \\
\text { Cardiomyopathy }\end{array}$ & $\begin{array}{l}24 \\
14\end{array}$ & $\begin{array}{l}\text { Frontal } \\
\text { Frontal }\end{array}$ \\
\hline Epilepsy & 8 & F & Lennox Gastaut & $\begin{array}{l}\text { Felbamate, } \\
\text { topiramate }\end{array}$ & Unknown & 8 & Frontal \\
\hline Control & 8 & F & & None $^{\mathrm{a}}$ & Arrhythmia & 12 & Frontal \\
\hline Epilepsy & 9 & M & Tonic-clonic & $\begin{array}{l}\text { Phenytoin, } \\
\text { valproate, } \\
\text { lamotrigine }\end{array}$ & Unknown & 17 & Parietal \\
\hline Control & 8 & M & & None & Trauma & 14 & Parietal \\
\hline Epilepsy & 15 & M & Tonic-clonic & $\begin{array}{l}\text { Phenytoin, } \\
\text { phenobarbital }\end{array}$ & Unknown & 26 & Frontal \\
\hline Control & 14 & M & & None & Trauma & 12 & Frontal \\
\hline
\end{tabular}

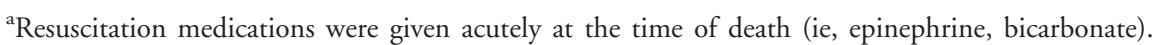

The data presented in this paper demonstrates increased expression of CRH, CRH-BP, and CRH-R1 in brain tissue obtained from children with generalized epilepsy. The expression levels of CRH-R2 were unchanged. These findings support the theory that elevated activity of the CRH system may either initiate or support ongoing seizure activity in children.

$\mathrm{CRH}$ production is immediately increased following stressful events ${ }^{2}$ and CRH is a potent convulsant in the developing brain via CRH-R1. ${ }^{6,7}$ Consequently, it has been suggested that chronic alterations in the $\mathrm{CRH}$ system secondary to stressful events may underlie some forms of seizure activity in children. ${ }^{1}$ Indeed, it is wellknown that fever, hypoxia, hypoglycemia, and trauma result in rapid increases in CRH production and are potent triggers for initiating seizure activity in children. ${ }^{1}$ Moreover, repeated stressful events during development can result in a chronic elevation of CRH production and release. ${ }^{12}$ Hence, severe or repeated stress during early development may cause or predispose children to epilepsy via elevated CRH activity. Until this study, however, no human data existed to corroborate this theory. Our results show a conclusive increase in both the expression of CRH and CRH-R1 that would effectively enhance the excitability elicited by the CRH system, including overt seizure activity. The CRH-BP mRNA was also elevated, which may serve to regulate the bioavailability of CRH following CRH-R1 activation. ${ }^{5}$ Compensatory increases in CRH-BP gene expression, which parallel elevated $\mathrm{CRH}$ production, are also observed following kindling-induced seizure activity in animals. ${ }^{8}$ Expression of CRH-R2 is statically reg- ulated during development ${ }^{13}$ and was unchanged in this study.

$\mathrm{CRH}$ is produced in the nonspiny bipolar neurons of layers II and III within the cerebral cortex. ${ }^{14}$ In contrast, immunostaining for CRH-R1 shows widespread distribution throughout layers II to VI. ${ }^{15} \mathrm{CRH}-\mathrm{R} 1$ is localized to the plasma membrane along the soma and proximal dendrites of neurons, ${ }^{15}$ an anatomical area that receives incoming synaptic potentials and performs signal integration. Hence, CRH is produced and released locally by spatially restricted interneurons, thereby modulating the excitability of principle neurons with widespread projections in cortical structures. Both CRH and CRH-R1 are therefore strategically localized to synchronize both normal and pathological levels of neuronal excitability. The CRH-BP is appropriately co-localized to structures with prominent immunostaining for $\mathrm{CRH}^{14}$ and expressed by both neurons and astrocytes. ${ }^{16}$

Recent studies suggest that CRH plays an important role in cognitive and motor development. For example, injection of $\mathrm{CRH}$ into the hippocampus improves memory retention and induces a long-lasting enhancement of synaptic efficacy. ${ }^{17}$ In cerebellar tissue, endogenous CRH release plays a permissive role in long-term depression, a form of synaptic plasticity related to motor learning. ${ }^{18}$ As many children with seizure disorders have associated psychomotor delay, ${ }^{19}$ it is also possible that chronic overactivity of the CRH system may result in impaired learning and development. Indeed, prolonged CRH-induced seizures in young animals result in neuronal death and synaptic reorganization; ${ }^{6,7}$ 

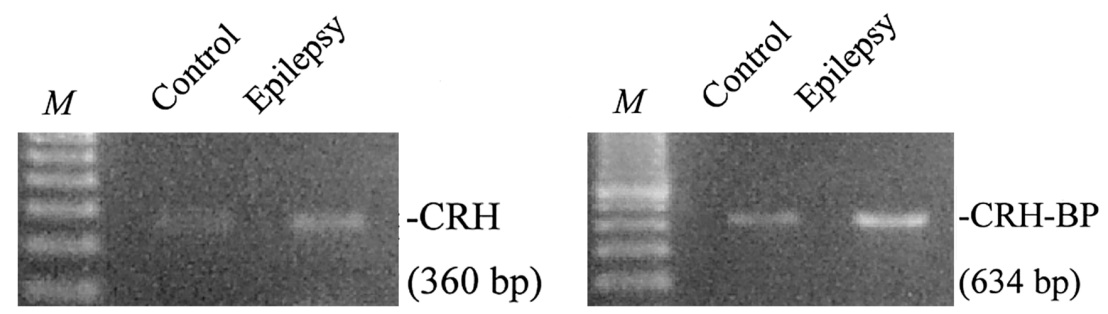

A

$\mathrm{D}$
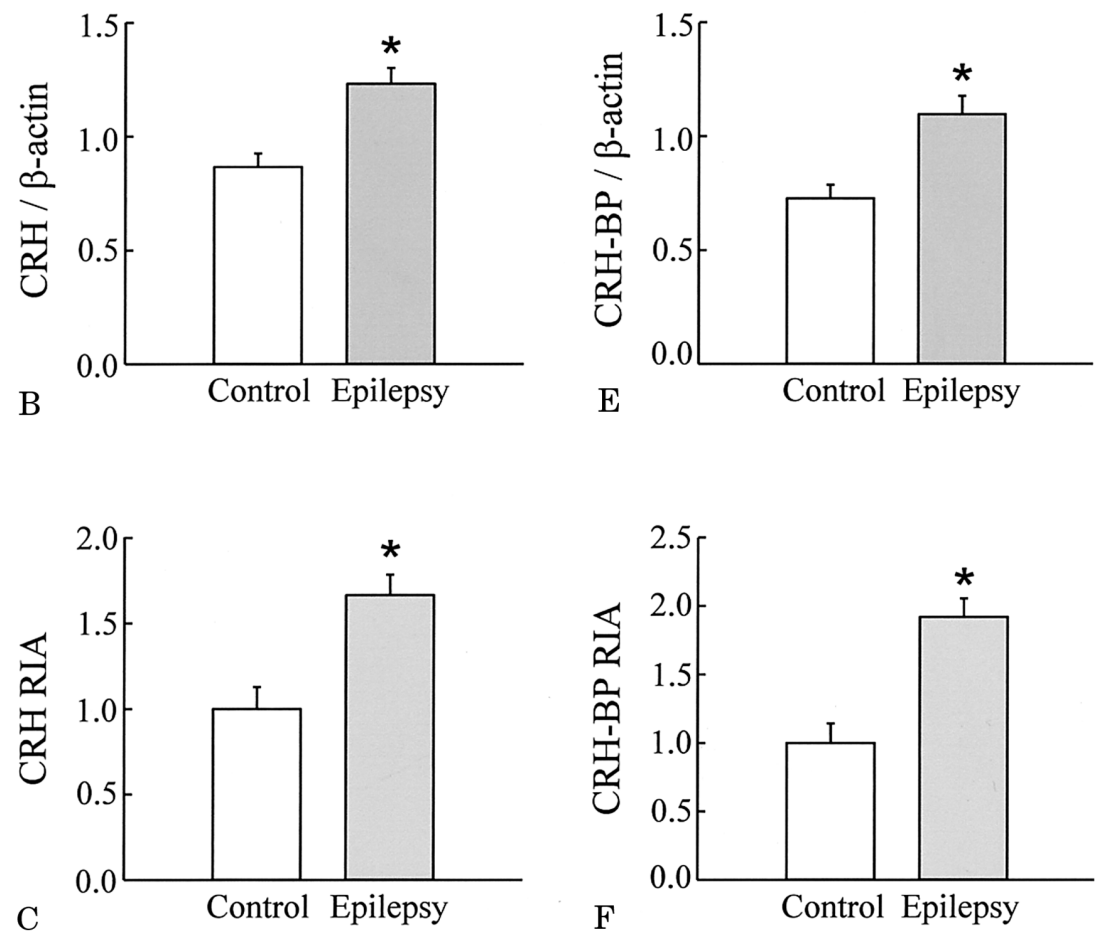

Fig 1. CRH and CRH-BP expression in postmortem cerebral cortex obtained from children with generalized epilepsy and age-matched controls. (A) Representative RT-PCR gels illustrating CRH (360 bp) bands from postmortem cortical tissue obtained from a child with epilepsy and their age-matched control. The intensity of the CRH band at 360 bp is greater in the lane labeled Epilepsy. (B) A plot illustrating the statistically significant $(\mathrm{p}<0.05)$ difference in CRH mRNA in postmortem cortical tissue obtained from children with epilepsy (epilepsy, $n=6$ ) and their age-matched controls (control, $n=6$ ). (C) Another plot illustrating the statistically significant difference in CRH $(\mathrm{p}<0.05)$, as measured by RIA, in postmortem cortical tissue obtained from children with epilepsy (epilepsy, $n=6$ ) and their age-matched controls (control, $n=6$ ). (D) Representative RT-PCR gels illustrating CRH-BP (634 bp) bands from postmortem cortical tissue obtained from a child with epilepsy and their age-matched control. The intensity of the CRH-BP band at 634 bp is greater in the lane labeled Epilepsy. (E) A plot illustrating the statistically significant $(\mathrm{p}<0.05)$ difference in $C R H-B P$ mRNA in postmortem cortical tissue obtained from children with epilepsy (epilepsy, $n=6$ ) and their age-matched controls (control, $n=6)$. (F) A plot illustrating the statistically significant $(\mathrm{p}<0.05)$ difference in CRH-BP, as measured by RIA, in postmortem cortical tissue obtained from children with epilepsy (epilepsy, $n=6$ ) and their age-matched controls (control, $n=6$ ).

changes that may parallel the cognitive decline observed in severe seizure disorders. ${ }^{19}$

The results of this paper support the theory that the $\mathrm{CRH}$ system plays a role in seizure genesis during development. It is not clear if these findings reflect a cause of seizure activity or an adaptive response supporting ongoing epileptogenesis. The development of infantile spasms, for example, is suggested to be caused by excess CRH production in response to stressinduced alterations in the brain-adrenal axis during antenatal/perinatal development. ${ }^{20}$ Indeed, systemic ACTH administration, which mimics the clinical treatment of infantile spasms, has recently been demonstrated to downregulate $\mathrm{CRH}$ gene expression in cen- 

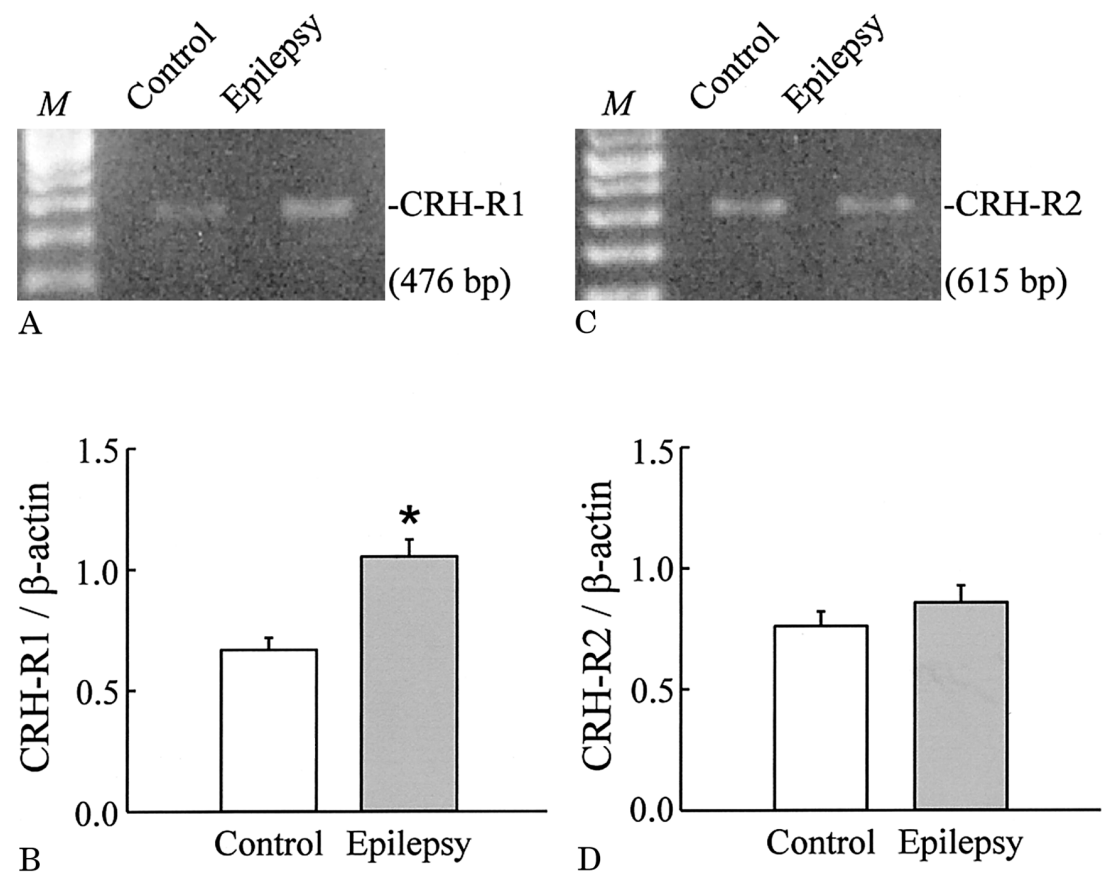

Fig 2. RT-PCR of CRH-R1 and CRH-R2 $m R N A$ in postmortem brain obtained from children with generalized epilepsy and their age-matched controls. (A) Representative RT-PCR gels illustrating CRH-R1 (476 bp) bands from postmortem cortical tissue obtained from a child with epilepsy and their age-matched control. The intensity of the CRH-RI band at 476 bp was greater in the lane labeled Epilepsy. (B) A plot illustrating the statistically significant $(\mathrm{p}<0.05)$ difference in CRH-R1 mRNA in postmortem cortical tissue obtained from children with epilepsy $(n=6)$ and their age-matched controls $(\mathrm{control}, n=6)$. (C) Representative RT-PCR gels illustrating CRH-R2 (615 bp) bands from postmortem cortical tissue obtained from a child with epilepsy and their age-matched control. The intensities of the CRH-R2 bands at $634 \mathrm{bp}$ are similar for the lanes labeled Control and Epilepsy. (D) A plot illustrating that no statistically significant difference in CRH-R2 mRNA was found in postmortem cortical tissue obtained from children with epilepsy (epilepsy, $n=6)$ and their age-matched controls (control, $n=6)$.

tral neurons from infant rats. ${ }^{20}$ It is also feasible that stressful events during postnatal development may result in chronic alterations in the CRH system and contribute to other forms of seizure genesis. ${ }^{1}$ Our data demonstrate elevated CRH and CRH-R1 expression in postmortem cerebral cortex obtained from children with generalized epilepsy, thereby supporting the above theory. Hence, our findings have important implications for therapeutics, as recently designed CRH-R1 antagonists $^{4}$ may demonstrate utility as novel anticonvulsant medications.

Financial support to D.D.F. includes Queen's University (Botterell Foundation, Advisory Research Council and Angada Foundation), the Savoy Foundation for Epilepsy Research, the Physicians' Services Incorporated Foundation, and the American Academy of Pediatrics.

We thank Drs L. Carmant, A. MacDonald, B. A. MacVicar, and Y. Tse for constructive comments on this manuscript, and Dr. P. Ji for technical assistance. We are indebted to the members of the Brain and Tissue Bank for Developmental Disorders at the University of Maryland and University of Miami for their assistance with this project. Antibody 5144 to CRH-BP was kindly provided by Dr W. Vale, The Salk Institute, La Jolla, CA.

\section{References}

1. Baram TZ, Hatalski CG. Neuropeptide-mediated excitability: a key triggering mechanism for seizure generation in the developing brain. Trends Neurosci 1998;21:471-476.

2. Hsu DT, Chen FL, Takahashi LK, Kalin NH. Rapid stressinduced elevations in corticotropin-releasing hormone mRNA in rat central amygdala nucleus and hypothalamic paraventricular nucleus: an in situ hybridization analysis. Brain Res 1998; 788:305-310.

3. Pich EM, Lorang M, Yegeneh $M$, et al. Increase of extracellular corticotropin-releasing factor-like immunoreactivity levels in the amygdala of awake rats during restraint stress and ethanol withdrawal as measured by microdialysis. J Neurosci 1995;15: $5439-5447$.

4. McCarthy JR, Heinrichs SC, Grigoriadis DE. Recent advances with the CRF1 receptor: design of small molecule inhibitors, receptor subtypes and clinical indications. Curr Pharm Des 1999;5:289-315.

5. Behan DP, De Souza EB, Lowry PJ, et al. Corticotropin releasing factor (CRF) binding protein: a novel regulator of $\mathrm{CRH}$ and related peptides. Front Neuroendocrinol 1995;16:362-382.

6. Baram TZ, Shultz L. Corticotropin-releasing hormone is a rapid and potent convulsant in the infant rat. Dev Brain Res 1991;61:97-101.

7. Baram TZ, Ribak CE. Peptide-induced infant status epilepticus causes neuronal death and synaptic reorganization. Neuroreport $1995 ; 6: 277-280$. 
8. Smith MA, Weiss SR, Berry RL, et al. Amygdala-kindled seizures increase the expression of corticotropin-releasing factor (CRF) and CRF-binding protein in GABAergic interneurons of the dentate hilus. Brain Res 1997;745:248-256.

9. Piekut DT, Phipps B. Corticotropin-releasing factor immunolabeled fibers in brain regions with localized kainate neurotoxicity. Acta Neuropathol 1999;98:622-628.

10. Masui JS, Morinobu S, Takahashi Y, et al. Elevated neuropeptide $\mathrm{Y}$ and corticotropin-releasing factor in the brain of a novel epileptic mutant rat: Noda epileptic rat. Brain Res 1999;833: 286-290.

11. Baram TZ, Chalmers DT, Chen C, et al. The $\mathrm{CRF}_{1}$ receptor mediates the excitatory actions of corticotropin releasing factor (CRF) in the developing rat brain: in vivo evidence using a novel, selective, non-peptide CRF receptor antagonist. Brain Res 1997;770:89-95.

12. Graham YP, Heim C, Goodman SH, et al. The effects of neonatal stress on brain development: implications for psychopathology. Dev Psychopathol 1999;11:545-565.

13. Eghbal-Ahmadi M, Hatalski CG, Lovenberg TW, et al. The developmental profile of the corticotropin releasing factor receptor $\left(\mathrm{CRF}_{2}\right)$ in rat brain predicts distinct age-specific functions. Dev Brain Res 1998;107:81-90.

14. Potter E, Behan DP, Linton EA, et al. The central distribution of a corticotropin-releasing factor (CRF)-binding protein predicts multiple sites and modes of interaction with CRH. Proc Natl Acad Sci U S A. 1992;89:4192-4196.

15. Chen Y, Brunson KL, Müller MB, et al. Immunocytochemical distribution of corticotropin-releasing hormone receptor type-1 $\left(\mathrm{CRF}_{1}\right)$-like immunoreactivity in the mouse brain: light microscopy analysis using an antibody directed against the C-terminus. J Comp Neurol 2000;420:305-323.

16. Behan DP, Maciejewski D, Chalmers D, De Souza EB. Corticotropin releasing factor binding protein (CRF-BP) was expressed in neuronal and astrocytic cells. Brain Res 1995;698: 259-264.

17. Radulovic J, Rühmann A, Liepold T, Spiess J. Modulation of learning and anxiety by corticotropin-releasing factor (CRF) and stress: differential roles of CRF receptors 1 and 2. J Neurosci 1999; 19:5016-5025.

18. Miyata M, Okada D, Hashimoto K, et al. Corticotropinreleasing factor plays a permissive role in cerebellar long-term depression. Neuron 1999;22:763-775.

19. Baram TZ. Pathophysiology of massive infantile spasms: perspective on the putative role of the brain adrenal axis. Ann Neurol 1993;33:231-236.

20. Brunson KL, Khan N, Eghbal-Ahmadi M, Baram TZ. Corticotropin (ACTH) acts directly on amygdala neurons to downregulate corticotropin-releasing hormone gene expression. Ann Neurol 2001;49:304-312.

\section{Early-Onset Multisystem Mitochondrial Disorder Caused by a Nonsense Mutation in the Mitochondrial DNA Cytochrome $C$ Oxidase II Gene}

Yolanda Campos, MSc, ${ }^{1}$ Alberto García-Redondo, MSc, ${ }^{1}$ Miguel A. Fernández-Moreno, $\mathrm{PhD},{ }^{2}$

Mercedes Martínez-Pardo, $\mathrm{MD}^{3}$

Guillermo Goda, Pharm B, ${ }^{1}$ Juan C. Rubio, MSc, ${ }^{1}$

Miguel A. Martín, Pharm B, ${ }^{1}$ Pilar del Hoyo, Pharm B, ${ }^{1}$ Ana Cabello, MD, ${ }^{1}$ Belen Bornstein, MD, ${ }^{2}$

Rafael Garesse, $\mathrm{PhD},{ }^{2}$ and Joaquín Arenas, $\mathrm{PhD}^{1}$

We report the first nonsense mutation (G7896A) in the mtDNA gene for subunit II of cytochrome $c$ oxidase (COX) in a patient with early-onset multisystem disease and COX deficiency in muscle. The mutation was heteroplasmic in muscle, blood, and fibroblasts from the patient and abundantly present in COX-deficient fibers, but less abundant in COX-positive fibers; it was not found in blood samples from the patient's asymptomatic maternal relatives. Immunoblot analysis showed a reduced concentration of both COX II and COX I polypeptides, suggesting impaired assembly of COX holoenzyme.

Ann Neurol 2001;50:409-413

Genetic defects leading to isolated cytochrome c oxidase (COX) deficiency have been elucidated only in the past few years. Several mutations have been found in all three mtDNA-encoded $C O X$ genes $^{1-9}$ and in nuclear genes that affect COX maturation and assembly, such as SURF-1, COX10, and SCO2. ${ }^{10}$ COX deficiency is the most commonly recognized respiratory chain defect in childhood, and clinical presentations are very heterogeneous, ranging from pure myopathy to devastating encephalomyopathy.

From the ${ }^{1}$ Centro de Investigación and Departamento de Neuropatología, Hospital Universitario, Madrid; ${ }^{2}$ Instituto Investigaciones Biomédicas "Alberto Sols" UAM-CSIC, Madrid; and "Departamento de Pediatría, Hospital Universitario Ramón y Cajal, Madrid, Spain.

Received Feb 5, 2001, and in revised form Jun 12. Accepted for publication Jun 12, 2001.

Address correspondence to $\mathrm{Dr}$ Arenas, Centro de Investigación, Hospital Universitario 12 de Octubre, Avda Córdoba km 5.4, 28041 Madrid, Spain. E-mail: jarenas@h12o.es 
In this report, we identified the first stop-codon mutation in the mtDNA-encoded COX II gene in a 3 -year-old girl with an early-onset multisystem mitochondrial disorder.

\section{Case Report}

The 3-year-old propositus was normal at birth but had psychomotor delay and failure to thrive since age 3 months. Examination at age 11 months showed short stature, low weight, microcephaly, skin abnormalities, severe hypotonia, and normal reflexes. Fundoscopy was consistent with pigmentary retinopathy. An electroencephalogram (EEG) was normal. Electrocardiography showed abnormal repolarization and echocardiography revealed left ventricular hypertrophy and thickening of the interventricular wall. Blood lactate was markedly elevated $(4.6 \mathrm{mmol} / \mathrm{L}$; normal $<2 \mathrm{mmol} / \mathrm{L})$. At age 15 months her symptoms and signs remained similar. Brainstem auditory evoked potentials (BAEPs) were decreased in amplitude and latency. Brain MRI showed agenesis of corpus callosum and cortico-subcortical atrophy. Examination at age 2 years, including brain MRI and cardiological investigations, showed similar findings to those observed previously. Blood lactate levels were very increased $(5.9 \mathrm{mmol} / \mathrm{L})$. A recent clinical evaluation at age 3 years showed that she still failed to thrive and revealed marked hypotonia without peripheral hypertonia, microcephaly, mild limitations of eye movements, pigmentary retinopathy, and concentric hypertrophic cardiomyopathy with normal left ventricle function. EEG was normal, but during sleep there were occasional bursts of slow waves and isolated spikes. Blood lactate was $5.4 \mathrm{mmol} / \mathrm{L}$. Overall, the clinical course has remained stable for the past year. A muscle biopsy was performed at age 11 months. The family history is negative for neuromuscular disorders and there is no parental consanguinity.

\section{Muscle Histochemistry and Biochemistry}

Histochemical analysis of serial frozen muscle sections was performed as described. ${ }^{11}$ The activities of the respiratory chain complexes were performed in muscle homogenates as described previously ${ }^{12}$ and referred to that of citrate synthase (CS) to correct for mitochondrial volume.

Immunoblot analysis of equal amounts of total cell protein from muscle cells was performed as described elsewhere. ${ }^{13}$ Proteins were probed with antiserum against COX II and COX I subunits, ND1 subunit, and the beta subunit of $\mathrm{F}_{1}$-ATP synthase, and detected with the ECL kit (Amersham).

\section{Molecular Genetic Investigations}

We sequenced the 22 mitochondrial tRNA genes as well as the three COX genes as described. ${ }^{14}$ Mitochondrial DNA from muscle, blood, and fibroblasts of the proband and blood from 2 maternal relatives was amplified using polymerase chain reaction (PCR) and sequenced in an ABIPrism 310 DNA sequencer and the cycle dye terminator DNA sequencing kit of Applied Biosystems (Perkin Elmer-Applied Biosystems, Foster City, CA).

To screen for the novel G7896A mutation we used primers corresponding to nt positions 7,750-7,771 (forward) and $8,349-8,329$ (backward) $^{15}$ to PCR-amplify a 599-bp frag- ment. In the wild-type mtDNA, there is a restriction site for the endonuclease Sca I, yielding fragments of 336 and 263 bp. The mutant sequence creates an additional restriction site for the endonuclease Sca I within the $263 \mathrm{bp}$ fragment, yielding products of 148 and $115 \mathrm{bp}$. To quantitate the proportion of mutant mtDNA, $\alpha-\mathrm{P}^{32}$ deoxyadenosine triphosphate was added in the last PCR cycle. ${ }^{16}$ Digested PCR products were run through a $10 \%$ nondenaturing polyacrylamide gel and subjected to autoradiography (Fig $1 \mathrm{~A}$ and $\mathrm{B}$ ).

Single-muscle fibers were isolated from $30-\mu \mathrm{m}$-thick cryostat cross section after COX staining. Selected normal and abnormal (ie, COX deficient) muscle fibers were processed as reported ${ }^{17}$ and subjected to PCR-RFLP analysis as described above.

\section{Results}

Histochemical examination of the muscle biopsy revealed an even reduction of COX activity but showed no COX-negative fibers. About $40 \%$ of the muscle fibers showed normal COX staining. SDH was normal, and no ragged-red fibers (RRF) were identified (Fig 2A and $\mathrm{B})$. Biochemical analysis of muscle homogenate revealed a single defect of COX activity, representing $13 \%$ of normal control values $(5.2 \mathrm{nmol} / \mathrm{min} / \mathrm{mg}$ protein/CS; normal value $41 \pm 10$ ), whereas all other respiratory chain complexes were normal.

Genetic analysis revealed the presence of a novel G7896A transition in COX II gene (see Fig 1B). PCRRFLP analysis showed that in the proband the mutation was heteroplasmic in muscle (76\%), blood (67\%), and fibroblasts (60\%; not shown) from the patient, but it was not detectable in blood from her mother or her sister (see Fig 1A). The mutation was not present in 30 patients with other mitochondrial diseases, with or without known point mutations, and in 80 normal controls.

Single-muscle fiber analysis showed that the mutant load in COX-deficient fibers $(\mathrm{n}=9 ; 70.8 \pm 8.1 \%)$ was significantly higher than that in COX-positive fibers $(\mathrm{n}=10 ; 17.6 \pm 17.8 \% ; p<0.0001$, MannWhitney $U$ test) (see Fig $1 \mathrm{~B}$ and 2C).

Immunoblot analysis revealed a $53 \%$ reduction $(53 \pm 5 \% ; \mathrm{n}=5, p<0.001$, Mann-Whitney $U$ test $)$ of COX II polypeptide and a $48 \%$ reduction (48 \pm $4 \% ; \mathrm{n}=5 ; p<0.001$, Mann-Whitney $U$ test) of COX I polypeptide compared to controls but failed to demonstrate the presence of truncated COX II polypeptides (Fig 3).

\section{Discussion}

The 3-year-old propositus showed a clinical phenotype whose most prominent features were early onset hypotonia, psychomotor delay, and marked lactic acidosis. In addition, she had failure to thrive, mild hypertrophic cardiomyopathy, and pigmentary retinopathy. Muscle histochemistry revealed abundant COXdeficient fibers, albeit there were neither COX-negative 


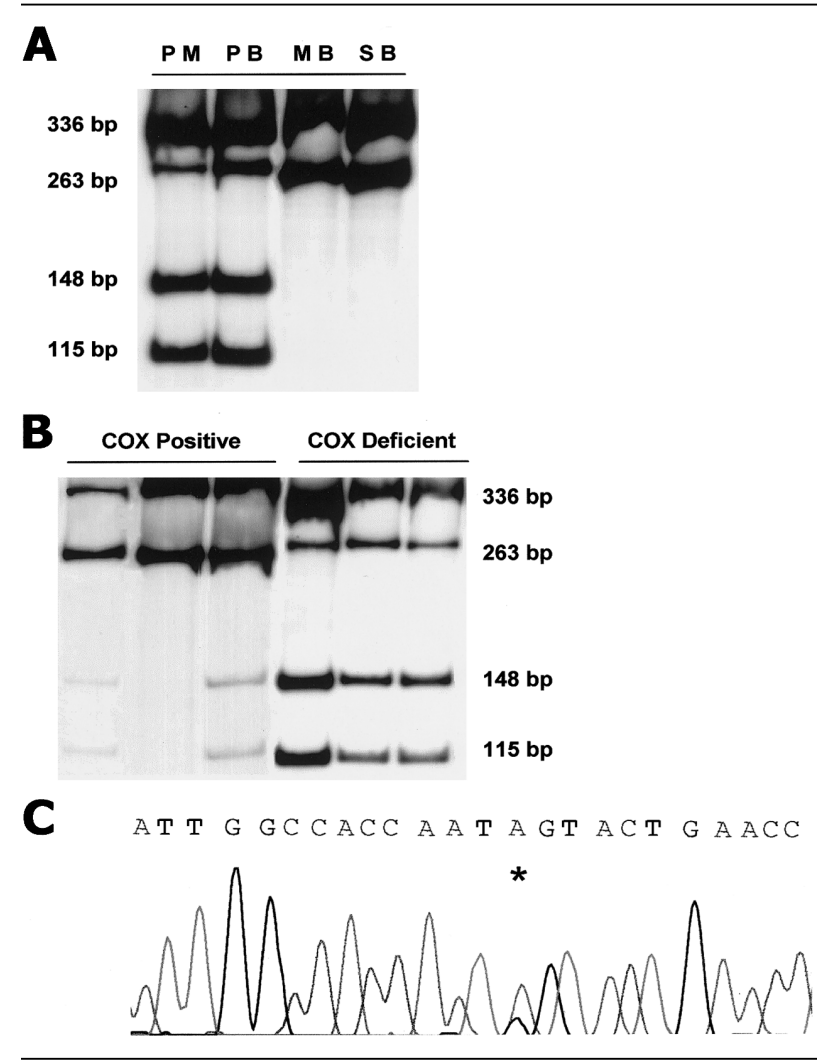

Fig 1. (A) PCR-RFLP analysis for the G7896A mutation. A 599-bp PCR product digested with Sca I results in two bands (336 bp and $263 \mathrm{bp)}$ if the wild type is present. In the presence of the mutation, the 263-bp frgament is cleaved into two fragments (148 bp and $115 \mathrm{bp}$ ). Mutant DNA was detected in the patient's muscle, blood, and fibroblasts (not shown), but not in blood of her mother or sister. Molecular sizes are indicated to the left of the gel. PM = patient's muscle; $\mathrm{PB}=$ patient's blood; $\mathrm{MB}=$ mother's blood; $\mathrm{SB}=$ sister's blood. (B) On single-fiber PCR analysis, the mutational load was greater in COX-deficient fibers than in COX-positive fibers. Molecular sizes are indicated to the right of the gel. (C) Chromatogram from fluorescent DNA sequencing. Asterisk represents the heteroplasmic $G$-to- $A$ transition at position 7,896 in $m t D N A$ COX II gene.

fibers nor RRF, and biochemical analysis showed a profound defect of COX activity. This prompted us to sequence the three mtDNA-encoded COX genes, which revealed a novel G7896A nonsense mutation in the COX II gene (see Fig 1C) that is predicted to cause premature termination of the translation, with a loss of 123 amino acids at the C-terminus of COX II. Several lines of evidence support the pathogenicity of this mutation. First, it was heteroplasmic in muscle, blood, and fibroblasts of the patient, a feature commonly associated with pathogenic mtDNA mutations, and especially nonsense ones. Second, it was absent in 110 nor$\mathrm{mal}$ and disease control individuals. Third, it correlated well with the marked biochemical defect (ie, isolated COX deficiency and reduction in COX II polypeptide)

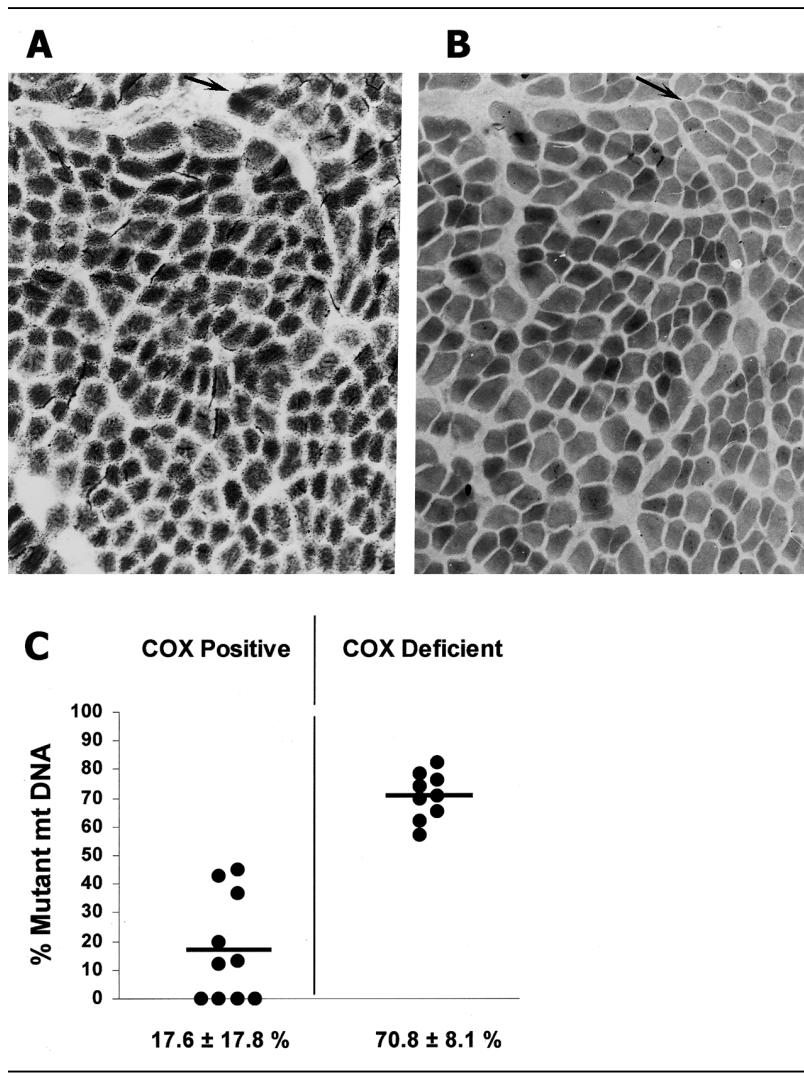

Fig 2. Histochemical reactions on serial muscle sections, for (A) SDH and (B) COX. SDH activity was normal. COX activity was reduced in many fibers. Arrow indicates one Type I fiber with reduced COX activity. (C) Proportion of the COX II G7896A mutation in single muscle fibers. The median proportion of mutant mtDNA in each fiber type is indicated by a horizontal line. The mean $\pm S D$ is shown below. The differences between COX-positive and COXdefective fibers were highly significant ( $\mathrm{p}<0.0001$; MannWhitney U test).

found in muscle. Moreover, single-fiber PCR studies clearly demonstrated a significant correlation between mutant-load level and COX activity in individual muscle fibers.

In the proband's muscle, which contained $76 \%$ mutant genomes, COX activity was decreased in many fibers, but there was no COX-negative fiber. These findings suggest an even distribution of mutant load in COX-deficient fibers, which was confirmed by singlefiber PCR analysis. We did not observe any RRF or signs of mitochondrial proliferation in the patient's muscle, but given the early age of the patient we cannot rule out the possibility that COX-negative fibers or RRF, or both, may appear later in muscle biopsy.

Although we could analyze only muscle, blood, and cultured cells from our patient, the multisystemic nature of her disease suggests that the G7896A mutation is also present in other tissues, including CNS and heart. A possible explanation for the lack of muscle 

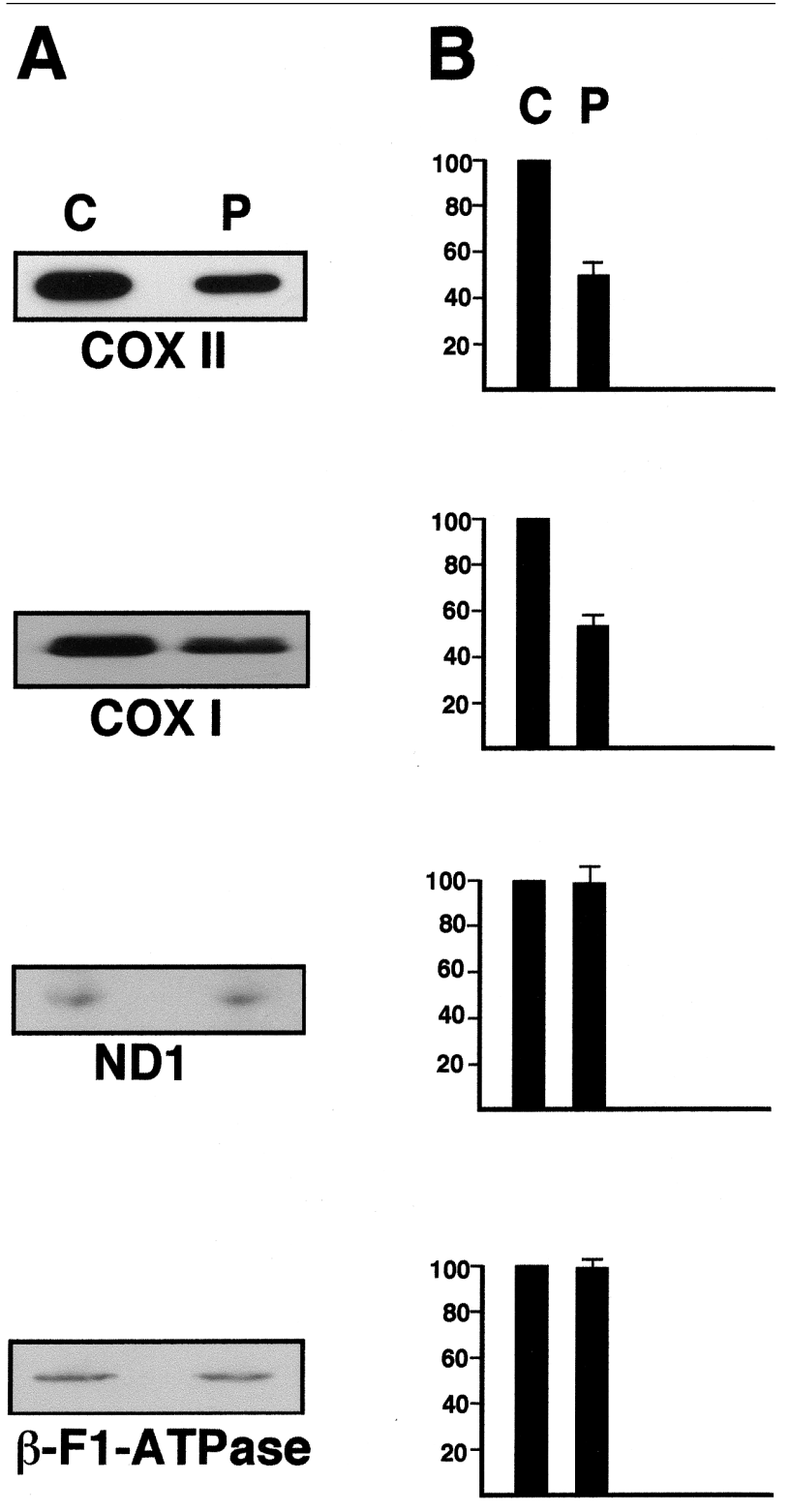

Fig 3. Immunodetection of COX polypeptides in control (C) and patient $(\mathrm{P})$ muscle biopsies. (A) Total protein extracted from control muscle was probed sequentially with anti-COX II, anti-COX I, anti-ND1, and anti-beta F1-ATPase antibodies. (B) Signals from at least four independent experiments were analyzed densitometrically. There was a significant reduction in the levels of both COX II and COX I $(\mathrm{p}<$ 0.001; Mann-Whitney $\mathrm{U}$ test $)$ in the muscle of the patient.

symptoms at age 3 years is that at such an early age the oxidative dysfunction is not severe enough to result in muscle phenotypic expression. Although the patient recently developed mild ophthalmoparesis, more prominent muscle symptoms (ie, exercise intolerance, limb muscle weakness, or both) may become apparent later in life. Consistent with this possibility, most patients with exercise intolerance, muscle weakness, or both, harboring a pathogenic mutation in the mtDNAencoded $C O X$ genes, were diagnosed during childhood, adolescence, or even adulthood. ${ }^{1-9}$ In fact, among the patients with mutations in mtDNA COX genes documented so far, this is the one with the earliest reported onset and is also the first one reported with cardiomyopathy and a lesser involvement of muscle.

Immunoblot analysis demonstrated a similar reduction of both COX II and COX I proteins. These data bolster the concept that mutations in the mtDNAencoded COX genes can impair assembly of the COX holoenzyme. ${ }^{5,8,9}$ The lack of truncated COX II peptides may indicate that they are rapidly degraded or may represent deletion of the antibody binding site on COX II polypeptide.

The encephalopathy and hypertrophic cardiomyopathy observed in our patient resemble those seen in patients with mutations in the nuclear-encoded SCO2 gene, ${ }^{10,18,19}$ although the latter usually show a more severe cardiomyopathy and a downhill clinical course. These clinical similarities may be the result of some common pathogenetic mechanism. A disruption in the $\mathrm{SCO} 2$ protein could impede the incorporation of $\mathrm{Cu}$ to the $\mathrm{Cu}_{\mathrm{A}}$ center of COX II polypeptide, as suggested by recent studies in both human and yeast. ${ }^{19,20}$ We suggest that, as a result of the G7896A mutation, the loss of the large hydrophobic domain of the COX II polypeptide that harbors the docking site for the $\mathrm{Cu}_{\mathrm{A}}$ center could likely result in a lack of incorporation of $\mathrm{Cu}$ to the structure of the protein. The differences in clinical severity may be accounted for by the presence of significant amounts of wild-type COX II protein in tissues of our patient, as shown by immunoblot studies in muscle.

In our patient the mutation seemed to be sporadic, as we did not find it in blood from any maternal relative examined. Therefore, it is likely that the mutation arose as a spontaneous event either during oogenesis or in early embryogenesis, as suggested by the fact that it was present in multiple tissues with different embryological derivation.

Supported by grants from Fondo de Investigación Sanitaria (F.I.S.) (00/0370) Ministerio de Sanidad, Spain; and from Dirección General de Investigación, Comunidad de Madrid (08.5/0013/2000). M. A. Martín was supported by Sigma-Tau, J. C. Rubio by F.I.S., A. García-Redondo by Asociación Española para el Estudio de la Esclerosis Lateral Amiotrófica (ADELA), and Y. Campos by a research contract from ISC III $(98 / 3166)$.

\section{References}

1. Keightley JA, Hoffbuhr KC, Buton MD, et al. A microdeletion in cytochrome $\mathrm{c}$ oxidase (COX) subunit III associated with COX deficiency and recurrent myoglobinuria. Nature Genet 1996;12:410-416.

2. Manfredi G, Schon EA, Moraes CT, et al. A new mutation associated with MELAS is located in a mitochondrial DNA polypeptide-coding gene. Neuromusc Disord 1995;5:391-398. 
3. Gattermann N, Retzlaff S, Wang YL, et al. Heteroplasmic point mutations of mitochondrial DNA subunit I of cytochrome c oxidase in two patients with acquired idiopathic sideroblastic anemia. Blood 1997;90:4961-4972.

4. Hanna MG, Nelson IP, Rahman S, et al. Cytochrome c oxidase deficiency associated with the first stop codon point mutation in mitochondrial DNA. Am J Hum Genet 1998;63:29-36.

5. Comi GP, Bordoni A, Salani S, et al. Cytochrome c oxidase subunit I microdeletion in a patient with motor neuron disease. Ann Neurol 1998;43:110-116.

6. Rahman S, Taanman JW, Cooper JM, et al. A missense mutation of cytochrome c oxidase subunit II causes defective assembly and myopathy. Am J Hum Genet 1999;63:1030-1039.

7. Clark KM, Taylor RW, Johnson MA, et al. A mtDNA mutation in the initiation codon of the cytochrome $c$ oxidase subunit II gene results in lower levels of the protein and a mitochondrial encephalopathy. Am J Hum Genet 1999;64: $1330-1339$.

8. Bruno C, Martinuzzi A, Tang YY, et al. A stop-codon mutation in the human mtDNA cytochrome $\mathrm{c}$ oxidase gene disrupts the functional structure of complex IV. Am J Hum Genet 1999; 65:611-620.

9. Karadimas CL, Greenstein P, Sue CM, et al. Recurrent myoglobinuria due to a nonsense mutation in the COX I gene of mitochondrial DNA. Neurology 2000;55:644-649.

10. Sue CM, Schon EA. Mitochondrial respiratory chain diseases and mutations in nuclear DNA: a promising start? Brain Pathol 2000;10:442-450.

11. Sciacco M, Bonilla E. Cytochemistry and immunocytochemistry of mitochondria in tissue sections. In: Attardi GM, Chomyn A, eds. Methods in enzymology. Vol. 264. Mitochondrial biogenesis and genetics. Part B. San Diego, CA: Academic Press, 1996:509-521.

12. Tiranti V, Chariot F, Carella A, et al. Maternally inherited hearing loss, ataxia and myoclonus associated with a novel point mutation in mitochondrial tRNA ${ }^{\mathrm{Ser}(\mathrm{UCN})}$ gene. Hum Mol Genet 1995;4:1421-1427.

13. Laemmli UK. Cleavage of structural proteins during the assembly of the head of bacteriophage T4. Nature 1970;227: 680-685.

14. Rieder MJ, Taylor SL, Tobe V, Nickerson DA. Automatic identification of DNA variations using quality-based fluorescence re-sequencing: analysis of the human mitochondrial genome. Nucleic Acid Res 1998;26:967-973.

15. Anderson S, Bankier AT, Barrel BG, et al. Sequence and organization of the human mitochondrial genome. Nature 1980; 290:457-465.

16. Tanno Y, Yoneda M, Nonaka Y, et al. Quantitation of mitochondrial DNA carrying tRNA ${ }^{\text {Lys }}$ mutation in MERRF patients. Biochem Biophys Res Commun 1991;179:880-885.

17. Moraes CT, Ricci E, Bonilla E, et al. The mitochondrial tRNA $^{\text {Leu(UUR) }}$ mutation in MELAS: genetic, biochemical and morphological correlations in skeletal muscle. Am J Hum Genet 1992;50:934-949.

18. Papadopoulou LC, Sue CM, Davidson MM, et al. Fatal infantile cardioencephalomyopathy with COX deficiency and mutations in SCO2, a COX assembly gene. Nat Genet 1999;23: 333-337.

19. Jaksch M, Ogilvie I, Yao J, et al. Mutations in SCO2 are associated with a distinct form of hypertrophic cardiomyopathy and cytochrome c oxidase deficiency. Hum Mol Genet 2000;9: 795-801.

20. Dickinson EK, Adams DL, Schon EA, Glerum DM. A human SCO2 mutation helps define the role of Scolp in the cytochrome c oxidase assembly pathway. J Biol Chem 2000;275: $26780-26785$.

\section{Ocular Flutter Associated with a Localized Lesion in the Paramedian Pontine Reticular Formation}

Fred Schon, FRCP, ${ }^{1}$ Timothy L. Hodgson, PhD, ${ }^{2}$ Dominic Mort, MRCP, ${ }^{2}$ and Christopher Kennard, FRCP ${ }^{2}$

Ocular flutter is a rare horizontal eye movement disorder characterized by rapid saccadic oscillations. It has been hypothesized that it is caused by loss of "pause" neuronal inhibition of "burst" neuron function in the paramedian pontine reticular formation (PPRF); however, there have been no imaging studies confirming such anatomical localization. We report the case of a woman with an acute attack of multiple sclerosis associated both with ocular flutter and a circumscribed pontine lesion, mainly involving the PPRF on magnetic resonance imaging. As she recovered from the attack, both the midline pontine lesion and the ocular flutter dramatically improved. This case is the first clear evidence that at least some cases of ocular flutter are due to lesions involving the PPRF.

Ann Neurol 2001;50:413-416

In 1954, Cogan first used the term "ocular flutter" ${ }^{1}$ to describe a rare disorder of horizontal eye movements characterized by rapid short bursts of synchronous back to back horizontal oscillatory movements usually seen in the primary position of gaze. Since then, there have been about 50 reports, usually single cases or small series, linking the phenomenon to a wide variety of brainstem and cerebellar conditions, but perhaps most frequently associated with parainfectious states, ${ }^{2}$ eg, as after enteroviral infection. ${ }^{3}$ Other reported cases include cerebral malaria, ${ }^{4}$ cyclosporine treatment, ${ }^{5}$ and meningitis. ${ }^{6}$ It is perhaps surprising that there are no reported cases in which there has been a clear anatomically localized lesion linked to ocular flutter. We describe a young woman with a definite relapse of her multiple sclerosis (MS) who developed prominent ocular flutter associated with a small focal lesion in the brainstem on magnetic resonance imaging (MRI).

From the ${ }^{1}$ Department of Neurology, Atkinson Morleys Hospital, Wimbledon, and ${ }^{2}$ Department of Neuroscience and Psychological Medicine, Imperial College School of Medicine, Charing Cross Campus, London, United Kingdom.

Received Feb 20, 2001, and in revised form Jun 11. Accepted for publication Jun 12, 2001.

Address correspondence to Dr Schon, Department of Neurology, Atkinson Morleys Hospital, Wimbledon SW 20 ONE, United Kingdom. 


\section{Case Report}

A 40-year-old Caucasian woman presented initially in 1997 with an episode of tingling mostly below her waist that lasted 2 weeks, followed in 1999 by a second episode of persistent numbness in her hands and feet without any major abnormal neurological signs. There was some slow improvement over a few months, but she again presented with a third episode in June of 2000, complaining of a 2-week history of unsteadiness on walking associated with an awareness that her eyes were jumping and vague feelings of double vision as well as urgency of micturition. On examination, she had mild gait ataxia but normal deep tendon reflexes and flexor plantar responses. The main finding was prominent ocular flutter without any obvious ophthalmoplegia or nystagmus. She was diagnosed as having clinically definite relapsing and remitting MS and treated with a 3-day course of intravenous methyl prednisolone.

Her routine blood tests were all normal; cerebrospinal fluid examination was not carried out, but her brain MRI scan showed multiple small periventricular lesions typical of MS radiating from the margins of the lateral ventricles and involving the anterior corpus callosum. In the posterior fossa, there was a single prominent small midline lesion just below the dorsal surface of the pons estimated to be $6 \mathrm{~mm}$ in length (Fig 1A and B). Reference to the MRI atlas by Kretschman and Weinrich ${ }^{7}$ confirmed this lesion to be at the level of the sixth nerve nuclei and to be virtually exactly occupying the position of the paramedian pontine reticular formation (PPRF). There were other far less obvious small areas of abnormal signal in the posterior fossa, including two in the left cerebellar hemisphere, one each in the right cerebellar hemisphere and the superior medulla.

Some weeks after the patient's acute presentation and after her main symptoms had started to subside, the patient agreed to have her eye movements recorded using a previously described ${ }^{8}$ infrared tracking method with a sample rate of $500 \mathrm{~Hz}$. These recordings confirmed the rapid back-toback saccadic oscillations typical of ocular flutter as shown in Figure 2. They also confirmed the presence of otherwise normal eye movements. The patient has continued to improve with minimal persistent gait ataxia and occasional episodes of ocular flutter.

The patient had a second brain MRI scan 8 months after the original one, in which the almost complete disappearance of the midline pontine lesion in the region of the PPRF was observed; a new lesion, however, was noted in the right cerebellar hemisphere.

\section{Discussion}

In 1979, Zee and colleagues studied a single patient with ocular flutter ${ }^{9}$ and related their findings to what was known about the anatomy and physiology of saccade generation in the monkey. They wrote a paper titled "A Hypothetical Explanation of Saccadic Oscillations" in which they proposed that "pause" neurons normally prevent saccadic oscillations during fixation by inhibiting "burst" neuron firing and that this mechanism is disturbed in ocular flutter. They later proposed a similar disturbance in both voluntary ${ }^{10}$ and blink-induced saccadic oscillations. ${ }^{11}$ They hypothesized that the anatomical site involved in this group of eye movement disorders, which also includes opsoclonus, would be in the medial region of the PPRF, which is the human equivalent of the pontine raphe interpositus nucleus (RIN), in which pause neurons are located in the monkey. ${ }^{12}$ In humans, it lies adjacent to the midline in the upper pons at the level of the sixth nerve nucleus, but slightly ventral to it. However, experimental lesions of the omnipause region with excitotoxins caused slow saccades rather than oscillations. One possible explanation is that burst neurons may also have been affected. ${ }^{13}$ Furthermore, Ridley and colleagues failed to detect any changes in the human homologue of the RIN at the light microscopic level in their postmortem study ${ }^{14}$ of 2 cases of paraneoplastic opsoclonus. It is important perhaps to point out that in their first case there were striking changes seen in the inferior olivary nucleus. These may be nonspecific, as such changes have also been reported in cases of paraneoplastic encephalomyelitis without opsoclonus, ${ }^{16}$ but other authors have suggested the cerebellum is the likely anatomical site causing opsoclonus. ${ }^{17,18}$

In contrast, a more recent postmortem study of a single patient who died 3 years after developing ataxia, opsoclonus, dementia, and a peripheral neuropathy, did show conspicuous changes in the PPRF with neuronal loss, perivascular lymphoid cuffing, and florid astrogliosis. ${ }^{16}$ It was not possible to be certain which classes of neurons were lost within the PPRF. This patient also had severe Purkinje cell loss in the cerebellum. No underlying malignancy was found, though she had high titers of the anti-Ri antibody.

This paper therefore offers perhaps the first clear-cut evidence linking ocular flutter to the region of the PPRF. The single, small, anatomically remarkably discrete lesion seen on MRI is located exactly in the region of the PPRF. The patient's lack of sixth nerve palsies or internuclear ophthalmoplegia further underlies its extremely discrete anatomical localization. It seems very unlikely that the other far less prominent posterior fossa lesions seen on the MRI scan were responsible for the patient's ocular flutter for 2 reasons: First, similar widespread lesions are often seen in cases of MS but have not been associated with ocular flutter, despite careful studies trying to correlate eye movement disorders with MRI changes; ${ }^{19}$ and second, there was a clear correlation between the clinical improvement in the patient's ocular flutter and the similar improvement seen in the midline MRI lesion in the region of the PPRF on the repeat MRI scan.

The only comparable case report is by AverbuchHeller and colleagues, in which they described a patient (who developed macrosaccadic oscillations 5 years after a head injury) in whom there was an MRI lesion in the right side of the pons extending upward from 

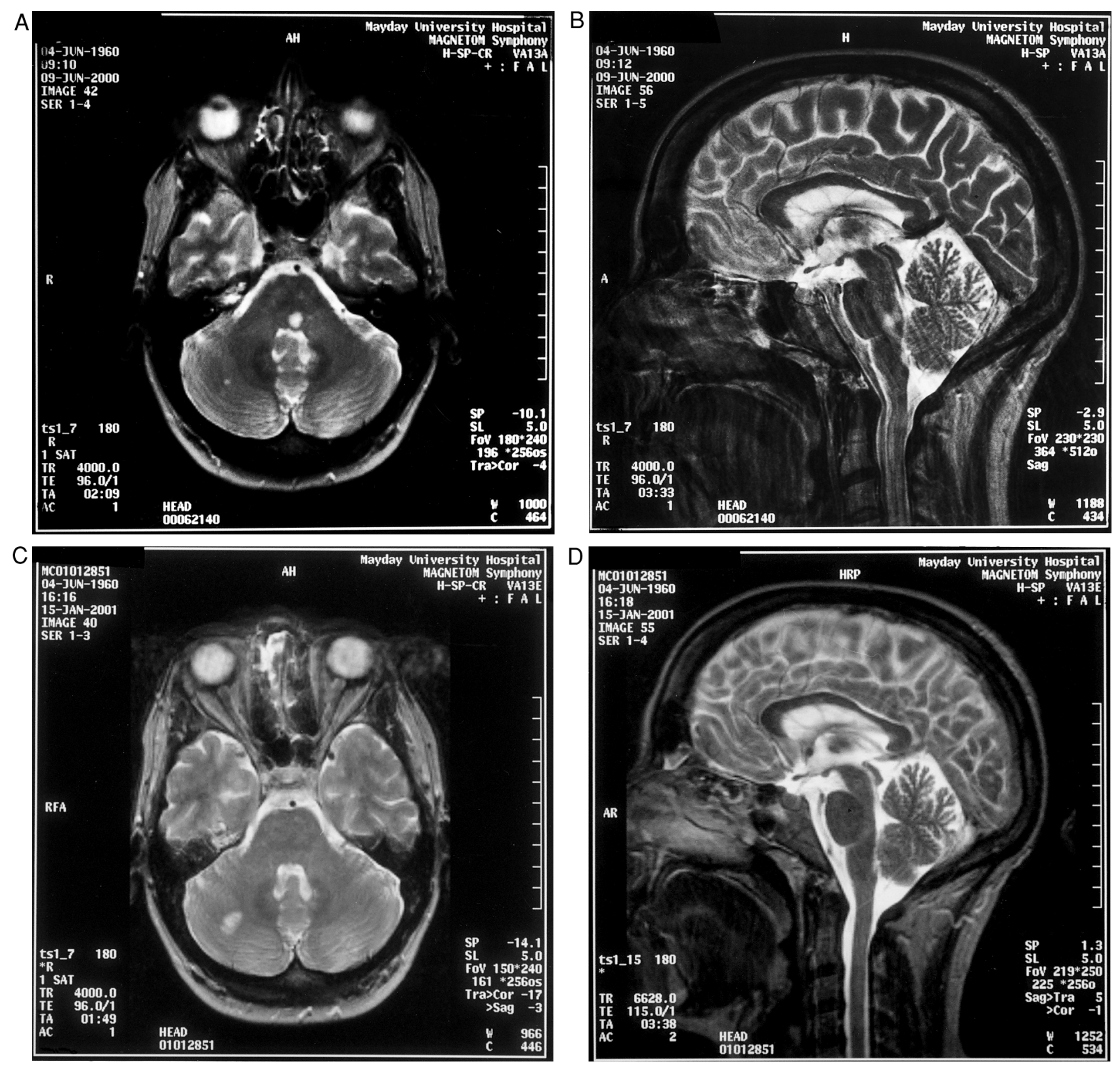

Fig. 1. (A) Axial brain MRI "FLAIR" sequence through the pons and medulla showing a single prominent midline high signal lesion in the region of the PPRF. (B) Sagittal midline section showing the same lesion demonstrating its cranio-caudal distribution and its subventricular localization. ( $C$ and D) Repeat axial and sagittal images through the same region 8 months later showing the disappearance of the midline pontine lesion.

the level of the sixth nerve nucleus into the tegmentum and basis pontis. It was proposed that the eye movement abnormality was caused by damage to the adjacent omnipause neuron projections. ${ }^{20}$

In conclusion, this case provides probably the most clear-cut evidence to date in support of the hypothesis linking ocular flutter to lesions in the PPRF. It does not explain why so many earlier cases have not shown a similar anatomical lesion, and it remains possible that there could be more than one anatomical site associated with disorders involving saccadic oscillations.
C.K., D.M., and T.H. are supported by the Wellcome Trust.

F.S. thanks Listerbestcare MRI unit for support with this study.

\section{References}

1. Cogan DG. Ocular dysmetria: flutterlike oscillations of the eyes, and opsoclonus. Arch Ophthalmol 1954;51:318-335.

2. Buttner U, Straube A, Handke V. Opsoclonus and ocular flutter. Nervenarzt 1997;68:633-637.

3. Wiest G, Safoshnik G, Schnarberth G, Mueller C. Ocular flutter and trunkal ataxia may be associated with enterovirus infection. J Neurol 1997;244:288-292. 


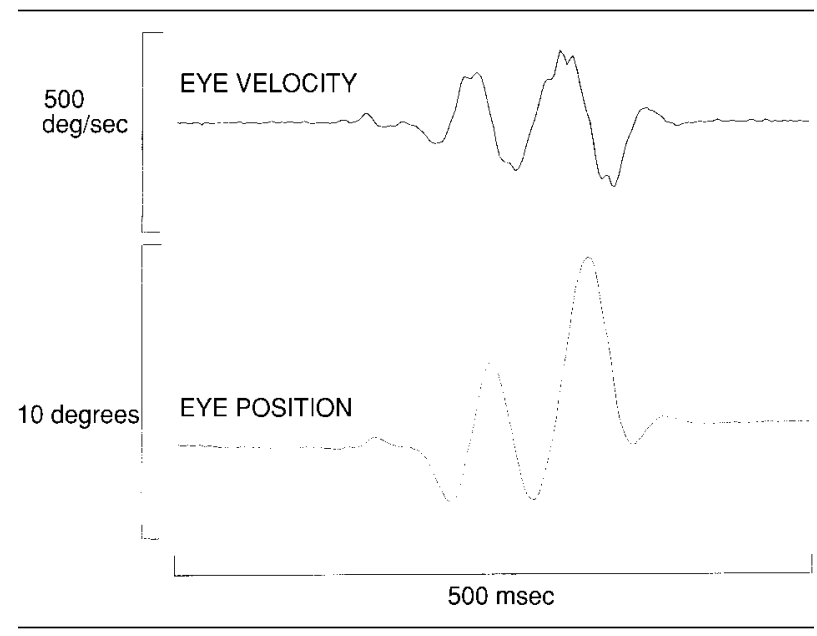

Fig. 2. A representative infrared oculographic recording showing the velocity in the upper trace and the position of the eyes in the lower trace during an individual episode of ocular flutter.

4. Idris MNA, Sokrab TEO. Post malaria cerebellar ataxia and ocular flutter: report of two cases. East Afr Med J 1999;7: 417-418.

5. Apsner R, Schulenburg A, Steinhoff N, et al. Cyclosporin A induced ocular flutter after marrow transplantation. Bone Marrow Transplant 1997;20:255-256.

6. Orimo S, Sato H, Ozawa E, et al. An autopsied case of purulent meningitis associated with ocular flutter. Brain Nerve 1998;50:469-472.

7. Kretschmann HJ, Weinrich W. Cranial neuroimaging and clinical neuroanatomy. Stuttgart: Thieme Verlag, 1992.

8. Hodgson TL, Dittrich W, Henderson L, Kennard C. Eye movements and spatial working memory in Parkinson's disease. Neuropsychologia 1999;37:927-938.

9. Zee DS, Robinson DA. A hypothetical explanation of saccadic oscillations. Ann Neurol 1979;5:405-414.

10. Yee RD, Spiegel PH, Yamada T, et al. Voluntary saccadic oscilations, resembling ocular flutter and opsoclonus. J Neuroophthamal 1994;14:95-101.

11. Hain TC, Zee DS, Mordes M. Blink-induced saccadic oscillations. Ann Neurol 1986;19:299-301.

12. Buttner-Ennever JA, Pause M. Neuroanatomic identification of the raphe nucleus in the pons associated with omnipause neurons of the oculomotor system in the monkey. J Comp Neurol 1988;267:307-321.

13. Kaneko CRS. Effect of ibotinic acid lesions of the omnipause neurons on saccadic eye movements in rhesus macaques. J Neurophysiol 1996;75:2229-2242.

14. Ridley A, Kennard C, Scholtz CL, et al. Omnipause neurons in two cases of opsoclonus associated with oat cell carcinoma of the lung. Brain 1987;110:1699-1709.

15. Hormingo A, Dalmau J, Rosenbaum MK, et al. Immunological and pathological study of anti-Ri-associated encephalopathy. Ann Neurol 1994;36:896-902.

16. Henson RA, Hoffman HL, Urich H. Encephalomyelitis with carcinoma. Brain 1965;88:449-464.

17. Ziter FA, Bray PF, Cancilla PA. Neuropathological findings in a patient with neuroblastoma and myoclonic encephalopathy. Arch Neurol 1979;36:51.

18. Hepp K, Henn V, Jaeger J. Eye movement related neurons in the cerebellar nuclei of the alert monkey. Exp Brain Res 1982; 45:253-264.

19. Bronstein AM, Rudge P, Gresty MA. Abnormalities of horizontal gaze. Clinical, oculographic and magnetic resonance imaging findings. II. Gaze palsy and internuclear ophthalmoplegia. J Neurol Neurosurg Psychiatry 1990;53:200-207.

20. Averbuch-Heller L, Kor AA, Rottach KG, et al. Dysfunction of pontine omnipause neurons causes impaired fixation: macrosoaccadic oscillations with a unilateral pontine lesion. Neuroophthalmology 1996;16:99-106. 